\title{
HUBUNGAN KADAR ASAM URAT DENGAN KEJADIAN GAGAL JANTUNG AKUT PADA PASIEN HIPERTENSI
}

\author{
${ }^{1}$ Rezuanto Pualillin \\ ${ }^{2}$ Starry H. Rampengan \\ ${ }^{2}$ Frans Wantania
}

\author{
${ }^{1}$ Kandidat Skripsi Fakultas Kedokteran Universitas Sam Ratulangi Manado \\ ${ }^{2}$ Bagian Ilmu Penyakit Dalam Fakultas Kedokteran Universitas Sam Ratulangi Manado \\ Email: rezuanto_pualillin@yahoo.co.id
}

\begin{abstract}
Long period of hypertension causes enlargement of the heart muscle, which leads to heart failure. Increased uric acid will causes endothelial dysfunction nas a result of the over production of reactive oxygen species (ROS), decrease the amount of nitric oxide (NO), increased rennin production, and the occurrence of inflammatory reactions. This speeds up the deterioration of the heart muscle, causing acute phase of heart failure. This study aimed to determine the relationship between uric acid levels and the incidence of acute heart failure in hypertensive patients in the emergency department and hypertension clinic of Prof. Dr R.D Kandou Hospital in Manado. This was an analytical observation by using the cross-sectional design. By using a non-probability sampling method we found 40 people as samples who had been diagnosed with heart failure due to hypertension. There were 15 samples that had experienced acute heart failure and 25 samples did not. Logistic Regression Test results stated that there was no significant effect of uric acid level with the incidence of acute heart failure (p $=0.188$ ), with the value of the odds ratio of 1.198. Conclusion: There was no correlation between the levels of uric acid with the incidence of acute heart failure in patients with hypertension.
\end{abstract}

Keywords: uricacid, hypertension, acute heart failure

\begin{abstract}
Abstrak: Hipertensi yang lama menyebabkan terjadinya pembesaran otot jantung sehingga berdampak pada terjadinya gagal jantung. Peningkatan asam urat juga menyebabkan disfungsi endotel akibat produksi reactive oxygen species (ROS) yang berlebihan, penurunan jumlah nitric oxide(NO), produksi renin meningkat, dan terjadinya reaksi inflamasi. Hal ini mempercepat perburukan otot jantung sehingga terjadi fase akut gagal jantung. Untuk mengetahui hubunganantara kadar asam urat dengan kejadian gagal jantung akut pada pasien hipertensidi instalasi rawat daruratdan poliklinik hipertensi RSUP Prof. Dr. R.D Kandou Manado. Jenis Penelitian ini adalah observasi analitik dengan menggunakan rancangan penelitian potong lintang. Dengan menggunakan metode non-probability sampling didapatkan 40 orang sebagai sampel yang telah didiagnosis menderita gagal jantung akibat hipertensi dimana 15 sampel yang mengalami episode akut dan 25 sampel yang tidak mengalami gagal jantung akut. Hasil Uji Regresi Logistik menyatakan bahwa tidak ada pengaruh yang signifikan antara kadar asam urat dengan kejadian gagal jantung akut $(\mathrm{p}=0,188)$, dengan nilai odds ratio sebesar 1,198. Simpulan: Tidak terdapat hubungan antara kadar asam urat dengan kejadian gagal jantung akut pada pasien hipertensi.
\end{abstract}

Kata kunci: asam urat, hipertensi, gagal jantung akut

Hipertensi adalah salah satu masalah umum, karena banyak orang yang menderitanya tetapi mereka tidak mengetahuinya sama sekali. Hipertensi 
didefinisikan sebagai peningkatan tekanan darah sistolik sedikitnya $140 \mathrm{mmHg}$ atau tekanan diastolik sedikitnya $90 \mathrm{mmHg}$. Hipertensi dapat menyebabkan kematian karena komplikasinya ke jantung atau disebut sebagai penyakit jantung hipertensi. Penyakit jantung hipertensi merupakan salah satu bentuk dari gagal jantung akut.Hipertensi merupakan salah satu penyebab utama kematian di dunia, dimana membunuh hampir 9,4 juta orang setiap tahun dan diperkirakan akan terus bertambah. Menurut World Health Organization (WHO) prevalensi hipertensi didunia tertinggi di Afrika (46\%) dan terendah di Amerika Serikat (35\%). Di Asia Tenggara sendiri, terdapat $36 \%$ orang dewasa yang menderita hipertensi. Berdasarkan Riset Kesehatan Dasar (Riskesdas) 2013, prevalensi hipertensi di Indonesia sebesar 26,5\%. Termasuk didalamnya, 95\% pasien hipertensi yang kontrol di tenaga kesehatan, dan 1\% pasien hipertensi minum obat sendiri tanpa kontrol di tenaga kesehatan. Di Sulawesi Utara hipertensi menempati urutan ke-8, dengan prevalensi $27,8 \%$. $^{1,2,3,4,5}$

Salah satu faktor resiko terjadinya hipertensi ialah asam urat yang meningkat (hiperurisemia). Muztafiza dalam penelitiannya melaporkan bahwa terdapat hubungan antara peningkatan kadar asam urat dengan terjadinya hipertensi. Berdasarkan prinsip ontology, jalur utama penyebab hipertensi pada keadaan hiperurisemia adalah disfungsi endotel akibat produksi reactive oksidatif stress (ROS) yang berlebihan dan penurunan nitrogen oksida (NO). Disfungsi endotel mengakibatkan lesi vaskuler ginjal dan menyebabakan hipertensi. Sebaliknya, hipertensi dapat juga mengakibatkan hiperurisemia. Berdasarkan penelitian sebelumnya, terjadinya hiperurisemia telah dihubungkan dengan penurunan sekresi asam urat dari tubulus ginjal. ${ }^{6-8}$

Asam urat juga merupakan salah satu faktor resiko yang dapat menyebabkan gagal jantung, baik secara langsung maupun tidak langsung. Pada penelitian yang dilakukan Tamariz et al, ditemukan bahwa pasien gagal jantung dengan hiperurisemia memiliki resiko kematian yang lebih tinggi jika dibandingkan dengan pasien yang kadar asam uratnya normal. Hal yang sama juga ditemukan pada penelitian yang dilakukan oleh Cerezo dan Ruilope, yang pada penelitiannya juga membuktikan bahwa peningkatan kadar asam urat meningkatkan morbiditas dan mortalitas pada pasien gagal jantung akut dan kronik. ${ }^{8-11}$

Namun, penelitian yang dilakukan oleh Culleton et al melaporkan bahwa menurut The Framingham Heart Study, peningkatan kadar asam urat tidak mempunyai peranan sebagai faktor risiko utama kejadian kardiovaskuler. ${ }^{12}$

Berdasarkan penjelasan di atas, maka peneliti tertarik mengangkat pemasalahan tersebut dalam penelitian ini dengan judul:

"Hubungan kadar asam urat dengan kejadian gagal jantung akut pada pasien hipertensi”.

\section{METODE PENELITIAN}

Penelitian ini bersifat observasi analitik dengan menggunakan desain potong lintang Penelitian ini dilakukan di instalasi rawat daruratdan poliklinik hipertensi RSUP Prof. Dr. R.D Kandou Manado, yaitu pada bulan November Desember 2014. Populasi dalam penelitian ini adalah pasien yang dirawat di instalasi gawat darurat RSUP Prof. Dr. R.D Kandou Manado.

Pengambilan sampel dilakukan secara non-probability sampling dengan menggunakan teknik consecutive sampling dengan besar jumlah sampel 40 orang.

\section{HASIL PENELITIAN}

Karakterisitik sampel dalam penelitian ini meliputi umur, jenis kelamin, pekerjaan, tekanan darah sistolik sebelum minum obat, tekanan darah diastolik sebelum minum obat, kadar asam urat dan kejadian gagal jantung akut. Untuk memperoleh gambaran distribusi menurut karakteristik sampel dapat dilihat pada tabel berikut: 
Tabel 1. Distribusi Karakteristik Sampel menurut Umur

\begin{tabular}{ccc}
\hline Umur & $\begin{array}{c}\text { Jumlah } \\
(\mathrm{n})\end{array}$ & $\%$ \\
\hline $31-50$ & 6 & 15,0 \\
tahun & & \\
$51-70$ & 30 & 75,0 \\
tahun & & \\
$>70$ tahun & 4 & 10,0 \\
\hline Total & 40 & 100,0 \\
\hline
\end{tabular}

Tabel 1 menunjukkan bahwa sampel yang berusia 51-70 tahun berjumlah lebih banyak yaitu sebanyak 30 orang (70\%), sedangkan sampel berusia lebih dari 70 tahun berjumlah lebih sedikit yaitu sebanyak 4 orang (10\%), diikuti dengan sampel berusia 31-50 tahun yaitu sebanyak 6 orang (15\%).

Tabel 2. Distribusi Karakteristik Sampel menurut Jenis Kelamin

\begin{tabular}{ccc}
\hline Jenis Kelamin & $\begin{array}{c}\text { Jumlah } \\
(\mathrm{n})\end{array}$ & $\%$ \\
\hline Laki-Laki & 21 & 52,5 \\
Perempuan & 19 & 47,5 \\
\hline Total & 40 & 100,0 \\
\hline
\end{tabular}

Tabel 2 menunjukkan bahwa sampel terbanyak ialah laki-laki yaitu 21 orang (52,5\%) sedangkan sampel perempuan berjumlah 19 orang $(47,5 \%)$.

Tabel 3. Distribusi Karakteristik Sampel menurut Pekerjaan

\begin{tabular}{ccc}
\hline Pekerjaan & $\begin{array}{c}\text { Jumlah } \\
\text { (n) }\end{array}$ & $\%$ \\
\hline PNS & 6 & 15,0 \\
Pekerja Swasta & 8 & 20,0 \\
Wiraswasta & \multicolumn{2}{c}{} \\
IRT & 2 & 5,0 \\
Pensiunan & 9 & 22,5 \\
& 15 & 37,5 \\
\hline Total & 40 & 100,0 \\
\hline
\end{tabular}

Tabel 3 diatas menunjukkan bahwa sampelterbanyak adalah dari kalangan pensiunan yaitu sebanyak 15 orang $(37,5 \%)$ dan sampel yang paling sedikit adalah sampel yang pekerjaannya sebagai wiraswasta yaitu sebanyak 2 orang (5\%). Sisanya ialah sampel dengan pekerjaan sebagai PNS sebanyak 6 orang (15\%), pekerja swasta sebanyak 8 orang (20\%) dan Ibu Rumah Tangga sebanyak 9 orang (22,5\%).

Tabel 4 menunjukkan bahwa sampel dengan tekanan darah sistolik 140-159 mmHg sebelum minum obat sebanyak 18 orang (45\%), sedangkan sampel dengan tekanan darah $<120 \mathrm{mmHg}$ sebanyak 1 orang $(2,5 \%)$.

Tabel 4. Distribusi Karakteristik Sampel menurut TDS sebelum Minum Obat

\begin{tabular}{ccc}
\hline TDS & $\begin{array}{c}\text { Jumlah } \\
(\mathrm{n})\end{array}$ & $\%$ \\
\hline$<120 \mathrm{mmHg}$ & 1 & 2,5 \\
$120-139 \mathrm{mmHg}$ & 16 & 40,0 \\
$140-159 \mathrm{mmHg}$ & 18 & 45,0 \\
$>160 \mathrm{mmHg}$ & 5 & 12,5 \\
\hline Total & 40 & 100,0 \\
\hline
\end{tabular}

Tabel 5. Distribusi Karakteristik Sampel menurut TDD sebelum Minum Obat

\begin{tabular}{ccc}
\hline TDD & $\begin{array}{c}\text { Jumlah } \\
\text { (n) }\end{array}$ & $\%$ \\
\hline$<80 \mathrm{mmHg}$ & 4 & 10,0 \\
$80-89 \mathrm{mmHg}$ & 3 & 7,5 \\
$90-99 \mathrm{mmHg}$ & 28 & 70,0 \\
$>100 \mathrm{mmHg}$ & 5 & 12,5 \\
\hline Total & 40 & 100,0 \\
\hline
\end{tabular}

Tabel 5 diatas menunjukkan bahwa sampel dengan tekanan darah diastolik 90$99 \mathrm{mmHg}$ sebelum minum obat sebanyak 28 orang (70\%), sedangkan sampel dengan tekanan darah diastolik $<80 \quad \mathrm{mmHg}$ sebanyak 4 orang (10\%).

Tabel 6. Distribusi Karakteristik Sampel menurut Kadar Asam Urat> 7 mg/dL

\begin{tabular}{ccc}
\hline $\begin{array}{c}\text { Kadar } \\
\text { Asam Urat }\end{array}$ & $\begin{array}{c}\text { Jumlah } \\
(\mathrm{n})\end{array}$ & $\begin{array}{c}\text { Persentase } \\
(\%)\end{array}$ \\
\hline$>7 \mathrm{mg} / \mathrm{dL}$ & 30 & 75,0 \\
$3-7 \mathrm{mg} / \mathrm{dL}$ & 10 & 25,0 \\
\hline Total & 40 & 100,0 \\
\hline
\end{tabular}

Tabel 6 diatas menunjukkan bahwa 
sampel dengan kadar asam urat $>7 \mathrm{mg} / \mathrm{dL}$ adalah sebanyak 30 orang (75\%), sedangkan sampel dengan kadar asam urat lebih 3-7 mg/dL sebanyak 10 orang (25\%).

Tabel 7. Distribusi Karakteristik Sampel menurut Kejadian Gagal Jantung Akut

\begin{tabular}{ccc}
\hline $\begin{array}{c}\text { Kejadian } \\
\text { Gagal Jantung } \\
\text { Akut }\end{array}$ & $\begin{array}{c}\text { Jumlah } \\
\text { (n) }\end{array}$ & $\%$ \\
\hline Ya & 15 & 37,5 \\
Tidak & 25 & 62,5 \\
\hline Total & 40 & 100,0 \\
\hline
\end{tabular}

Tabel 7 diatas menunjukkan bahwa sampel yang tidak mengalami kejadian gagal jantung akut adalah sebanyak 25 orang (62,5\%), sedangkan sampel yang mengalami kejadian gagal jantung akut sebanyak 15 orang $(37,5 \%)$.
Berdasarkan Tabel 8, melalui Uji Mann-Whitney terdapat 3 jenis karakteristik sampel yang tidak memiliki hubungan dengan kejadian gagal jantung akut atau nilai $\mathrm{p}>0,05$ yaitu umur dengan nilai $\mathrm{p}=0,053$; tekanan darah sistolik sebelum minum obat dengan nilai $\mathrm{p}=0,115$ dan tekanan darah diastolik sebelum minum obat dengan nilai $\mathrm{p}=0,317$, dan saat dilakukan Uji T Tidak Berpasangan, kadar asam urat juga tidak memiliki hubungan dengan kejadian gagal jantung akut dengan nilai probabilitas sebesar $0,256(\mathrm{p}>0,05)$. Demikian juga dengan Uji Chi-Square, ada 2 karakteristik sampel yang tidak memiliki hubungan dengan kejadian gagal jantung akut atau nilai $\mathrm{p}>0,05$ yaitu karakteristik jenis kelamin dengan nilai $\mathrm{p}=0,462$ dan karakteristik pekerjaan dengan nilai $\mathrm{p}=0,469$.

Tabel 8. Perbandingan Karakteristik Dasar Sampel yang Menderita Gagal Jantung Akut dan Tidak Menderita Gagal Jantung Akut

\begin{tabular}{|c|c|c|c|}
\hline \multirow{3}{*}{ Variabel } & \multicolumn{2}{|c|}{ Gagal Jantung Akut } & \multirow{3}{*}{ Nilai p } \\
\hline & Ya & Tidak & \\
\hline & $\mathrm{n}(\%)$ & n (\%) & \\
\hline \multicolumn{4}{|l|}{ Umur } \\
\hline$\overline{31-50}$ tahun & 26,7 & 8,0 & $0,053 * * *$ \\
\hline 51-70 tahun & 60,0 & 84,0 & \\
\hline$>70$ tahun & 13,3 & 8,0 & \\
\hline Total & 100 & 100 & \\
\hline \multicolumn{4}{|l|}{ Jenis Kelamin } \\
\hline$\overline{\text { Pria }}$ & 60,0 & 48,0 & $0,462 * *$ \\
\hline Wanita & 40,0 & 52,0 & \\
\hline Total & 100 & 100 & \\
\hline \multicolumn{4}{|l|}{ Pekerjaan } \\
\hline$\overline{\mathrm{PNS}}$ & 26,7 & 8,0 & $0,469 * *$ \\
\hline Pekerja Swasta & 20,0 & 20,0 & \\
\hline Wiraswasta & 0,0 & 8,0 & \\
\hline IRT & 20,0 & 24,0 & \\
\hline Pensiunan & 33,3 & 40,0 & \\
\hline Total & 100 & 100 & \\
\hline \multicolumn{4}{|l|}{ TDS } \\
\hline$\overline{<120} \mathrm{mmHg}$ & 6,7 & 0,0 & $0,115 * * *$ \\
\hline 120-139 mmHg & 40,0 & 40,0 & \\
\hline 140-159 mmHg & 26,7 & 56,0 & \\
\hline$>160 \mathrm{mmHg}$ & 26,7 & 4,0 & \\
\hline Total & 100 & 100 & \\
\hline
\end{tabular}




\begin{tabular}{cccc}
\hline$<80 \mathrm{mmHg}$ & 26,7 & 0,0 & $0,317^{* * *}$ \\
$80-89 \mathrm{mmHg}$ & 13,3 & 4,0 & \\
$90-99 \mathrm{mmHg}$ & 40,0 & 88,0 & \\
$>100 \mathrm{mmHg}$ & 20,0 & 8,0 & $0,256^{*}$ \\
\hline \multicolumn{1}{c}{ Total } & 100 & 100 & \\
\hline Kadar Asam & & 80,0 & \\
\hline Urat & 66,7 & 20,0 & \\
3-7 mg/dL & 33,3 & 100 \\
\hline
\end{tabular}

Berdasarkan Tabel 9, hasil analisis data dengan menggunakan Uji Regresi Logistik menyatakan bahwa tidak ada pengaruh yang signifikan antara kadar asam urat dengan kejadian gagal jantung akut $(\mathrm{p}=0,188)$. Nilai odds ratio 1,198 yang artinya peningkatan kadar asam urat akan memengaruhi kejadian gagal jantung akut sebesar 1,198 kali lipat.

Tabel 9. Hubungan KAU dengan GJA

\begin{tabular}{ccc}
\hline Variabel & Sig. & OR \\
\hline KAU & 0,188 & 1,198 \\
Constant & 0,095 & 0,122 \\
\hline
\end{tabular}

a. Variable(s) entered on step 1: KAU2.

\section{BAHASAN}

Penelitian ini bertujuan untuk mengetahui hubungan kadar asam urat dengan kejadian gagal jantung akut pada pasien hipertensidi instalasi rawat darurat dan poliklinik hipertensi RSUP Prof. Dr. R.D Kandou Manado. Pada penelitian ini digunakan kriteria yaitu kadar asam urat 3$7 \mathrm{mg} / \mathrm{dL}$ dan $>7 \mathrm{mg} / \mathrm{dL}$.

Hasil uji statistik memperlihatkan bahwa tidak ada hubungan yang signifikan antara kadar asam urat dengan kejadian gagal jantung akut pada pasien hipertensi. Pada kadar asam urat 3-7 mg/dL dan $>7$ $\mathrm{mg} / \mathrm{dL}$ didapatkan nilai $\mathrm{p}=0,188$ yang artinya tidak ada hubungan yang signifikan antara kadar asam urat dengan kejadian gagal jantung akut. Hasil penelitian ini tidak sesuai dengan Okafor Q. H et all yang menemukan adanya hubungan kadar asam urat dengan kejadian gagal jantung akut pada pasien hipertensi. Namun penelitian yang dilakukan oleh Okafor Q. H et al juga menggunakan kadar asam urat yang sesuai dengan penelitian ini yaitu kadar asam urat 3-7 mg/dL dan > $7 \mathrm{mg} / \mathrm{dL}$ menggunakan uji Pearson Chi- square. ${ }^{13}$

Hal ini dapat dikarenakan hanya terdapat 5 dari pada sampel yang hipertensi memiliki kadar asam urat $>7 \mathrm{mg} / \mathrm{dL}$ yang mengalami gagal jantung akut. Sedangkan terdapat 10 sampel yang memiliki kadar asam urat dibawah dari $\leq 7 \mathrm{mg} / \mathrm{dL}$ yang mengalami gagal jantung akut. Hal ini menunjukan bahwa peningkatan kadar asam urat bukan merupakan faktor utama pemicu terjadinya gagal jatung akut pada pasien hipertensi. Namun pada penelitian ini didapatkan hasil Odds Ratio ditunjukkan dengan nilai 0,5 yang artinya kadar asam urat diatas $>7 \mathrm{mg} / \mathrm{dL}$ beresiko meningkatkan kejadian gagal jantung akut sebesar $1 / 2$ kali lipat pada pasien hipertensi dari pada pasien yang kadar asam uratnya dibawah $<7 \mathrm{mg} / \mathrm{dL}$ atau memiliki resiko yang kecil untuk terjadinya gagal jantung akut. Sementara pada penelitian yang dilakukan oleh Okafor $Q$. $H$ et al lebih banyak ditemukan sampel dengan gagal jantug akut dibandingkan dengan sampelyang tidak mengalami gagal jantung akut. $^{13}$

Teori Framingham Heart Study yang menyatakan peningkatan kadar asam uratbukan merupakan faktor resikoutama kejadian gagal jantung akut.Namun merupakan salah satu faktor pendukung terjadinya gagal jantung akut. Hal ini dikarenakan peningkatan kadar asam urat 
berkontribusi terhadap munculnya gangguan produksi nitratoksida dan disfungsi endotel, peningkatan kekakuan pembuluh darah, aktivasi renin-angiotensin aldosteron yang tidak sesuai, peningkatan stres oksidatif, dan respon inflamasi. Semua kelainan ini menyebabkan gangguan fungsi dari pembuluh darah, jantung dan ginjal. Dijelaskan pada penelitian-penelitian sebelumnya kejadian gagal jantung akut disebabkan oleh multifaktorial. Diantaranya, gagal ginjal kronik, DMT2, obesitas, aterosklerosis dan akut miokard infark (AMI). ${ }^{13,14,15,16,17}$

Namun hasil penelitian ini tidak sesuai dengan hasil penelitianAlcaino $H$. et alyang menemukan nilai $\mathrm{p}=0,04(\mathrm{p}<0,05)$ yang artinya terdapat hubungan antara kadar asam urat dengan kejadian gagal jantung akut. Dari hasil penelitian yang dilakukan oleh Caraba A. et aljuga menyimpulkan bahwa tingginya kadar asam urat meningkatkan risiko gagal jantung akut yang berhubungan dengan disfungsi ginjal dan peradangan. ${ }^{16,18}$

Perbedaan ini dapat disebabkan oleh karena penelitian ini memiliki keterbatasan. Pertama, kurangnya jumlah sampel yang diteliti, kedua banyaknya pasien yang datang dengan berbagai macam komplikasi, yang mana komplikasi yang paling sering yaitu gagal ginjal kronik. Gagal ginjal kronik berdampak pada peningkatan dari pada asam urat dalam darah sehingga peningkatan asam urat sebelum terjadinya gagal jantung akut susah dievaluasi. Peningkatan kadar asam urat dalam darah itu sering kita kenal dengan istilah hiperurisemia. Hiperurisemia adalah keadaan dimana darah seseorang mengandung kadar asam urat diatas nilai normal. Kriteria hiperurisemia menurut Council For International Organisation of Medical Sciences (CIOMS) yaitu $>7 \mathrm{mg} / \mathrm{dL}$ untuk pria dan $>6 \mathrm{mg} / \mathrm{dL}$ untuk wanita. ${ }^{19}$

Terdapat banyak faktor-faktor yang dapat mempengaruhi peningkatan kadar asam urat di dalam darah, salah satunya adalah hipertensi. Keadaan hipertensi yang tidak terkontrol dalam waktu yang lama dapat mengakibatkan hipertrofi ventrikel kiri atau pembesaran ventrikel kiri oleh karena beban kerja jantung yang berat dalam memompa darah keseluruh tubuh. Pembesaran otot jantung akan memperburuk sirkulasi pembuluh darah koroner sehingga dapat menurunkan cadangan pembuluh darah koroner tersebut dan akan mengakibatkan gangguan perfusi miokard. ${ }^{20,21}$

Ginjal merupakan organ penting dalam proses ekskresi asam urat. Namun apabila fungsi ginjal terganggu maka akan terjadi peningkatan kadar asam urat di dalam darah. Peningkatan kadar asam urat dalam darah memiliki efek pada ginjal dan pembuluh darah. Kondisi ini disebut hiperurisemia yang dapat menyebabkan: 1) penurunan NO dan peningkatan ROS, 2) inflamasi vaskuler dan proliferasi otot polos, 3) peningkatan produksi renin, dan 4) lesi vaskuler pada ginjal. Proliferasi otot polos terjadi akibat aktivasi mitogen spesifik oleh asam urat. Walaupun otot polos tidak memiliki reseptor untuk asam urat, asam urat tetap dapat masuk ke dalam sel dengan bantuan organic anion transporter (OAT). Setelah masuk ke dalam sel otot polos, asam urat mengaktifkan protein kinase (Erk 1/2). Selanjutya Erk 1/2 akan menginduksi sintesis de novo dari COX-2 dan tromboksan lokal serta mengatur up regulation PDGF A (platelet derived growth factor A). Hasil akhir proses tersebut adalah aktivasi mitogen spesifik yang menyebabkan proliferasi sel. ${ }^{22}$

Asam urat juga menyebabkan akumulasi kristal urat di sekitar plak aterosklerosis yang telah terbentuk. Kristal urat tersebut dapat mengaktifkan komplemen melalui jalur klasik. Aktivasi komplemen mengakibatkan berbagai efek biologis seperti inflamasi, kemotaksis, opsonisasi, dan aktivitas sitolitik. Asam urat juga akan menstimulasi sintesis MCP1 (monocyte chemoattractant protein-1) pada otot polos. Caranya adalah dengan mengaktivasi p38 MAP kinase, faktor transkripsi nuklear, NF-кB, dan AP-1. MCP-1 sendiri merupakan kemokin yang berperan penting dalam penyakit vaskular 
dan aterosklerosis. Akibat dari mekanisme tersebut adalah peningkatan produksi sitokin proinflamasi seperti TNF-a, IL-1ß, dan IL-6. IL-6 yang juga dikenal sebagai hepatocyte stimulating factor merangsang hepatosit untuk memproduksi CRP. CRP menurunkan produksi NO dengan cara menghambat enzim nitrit oksidase sintase (eNOS). ${ }^{6,23}$

Lebih jauh lagi hiperurisemia akan menyebabkan perubahan mikrovaskuler pada ginjal yang mirip dengan gambaran arteriosklerosis pada hipertensi esensial. Lesi vaskuler tersebut menyebabkan iskemia. Selanjutnya iskemia menyebabkan pelepasan laktat dan peningkatan produksi asam urat. Laktat sendiri bersifat menghambat sekresi asam urat dengan memblok organic anion transporter. Peningkatan produksi asam urat terjadi karena iskemi menyebabkan pemecahan ATP menjadi adenosin dan xathine. Hal tersebut menciptakan suatu lingkaran setan. Kondisi hiperurisemia meningkatkan aktivitas enzim xathine oksidase. Padahal enzim tersebut juga membentuk superoksida sebagai akibat langsung aktivitasnya. Peningkatan jumlah oksidan menyebabkan stress oksidatif yang semakin menurunkan produksi NO dan memperparah disfungsi endotel yang terjadi. Lesi pada vaskuler ginjal ini akan memicu terjadinya salt sensitive hypertension yaitu peningkatan tekanan darah yang lebih tinggi pada konsumsi jumlah natrium yang sama. Kondisi ini menetap meskipun hiperurisemia telah dikoreksi dan diberikan diet rendah garam. Hal inilah yang dapat menyebabkan peningkatan kadar asam urat akan memperbesar faktor resiko gagal jantung akut. ${ }^{6,23}$

\section{SIMPULAN}

1. Berdasarkan hasil penelitian disimpulkan bahwa tidak terdapat hubungan antara kadar asam urat dengan kejadian gagal jantung akut pada pasien hipertensi yang dirawat di instalasi gawat darurat RSUP Prof. Dr. R.D Kandou Manado.
2. Terdapat $25 \%$ pasien hipertensi yang mengalami gagal jantung karena pengaruh dari kadar asam urat yang meningkat.

\section{SARAN}

1. Perlu dilakukan penelitian lebih lanjut lagi dengan jumlah sampel yang lebih besar lagi untuk melihat pengaruh tingginya kadar asam urat terhadap kejadian gagal jantung akut pada pasien hipertensi.

2. Perlu dilakukan uji multivariat dalam penelitian-penelitian selanjutnya untuk mengetahui pengaruh faktor-faktor lain yang dapat mengakibatkan gagal jantung akut pada pasien hipertensi.

\section{DAFTAR PUSTAKA}

1. Knight JF. Jantung Kuat Bernafas Lega. Bandung: Indonesia Publishing House; 2010. p. 71.

2. Price SA, Wilson LM. Penyakit Aterosklerotik Koroner. In: Brown CT, editor. Patofisiologi: Konsep Klinis Proses-Proses Penyakit. $6^{\text {th }}$ ed. Jakarta: EGC; 2012. p. 583.

3. WHO. World Health Day. 2013 [cited 2014 Oct 13].Available from: http://www.searo.who.int/entity/worl d_health_day/leaflet_burden_hbp_wh d_2013. pdf.

4. Kementrian Kesehatan RI. Riset Kesehatan Dasar (RISKESDAS). 2013 [cited 2014 Oct 13]. Available from: http://www.litbang.depkes.go.id/sites/ download/rkd2013/Laporan_Riskesda s2013.PDF.

5. Sudoyo WA, Setiyohadi B, Alwi I, Simadibrata M, Setiati S. Hipertensi Esensial. In: Yogiantoro, editor. Buku Ajar Ilmu Penyakit Dalam Jilid II. $5^{\text {th }}$ ed. Jakarta: Interna Publishing; 2009. p. 1079-85.

6. Mustafiza PV. Hubungan antara hiperurisemia dengan hipertensi [skripsi]. Surakarta: Fakultas Kedokteran Universitas Sebelas Maret; 2010.

7. Lingga L. Bebas penyakit asam urat tanpa obat. Jakarta: Agro Media Pustaka; 2012. p. 82.

8. Krishnan E. Hyperuricemia and incident heart failure. Circ Heart Fail. 
2009;2(6):556-62.

9. Tamariz L, Harzand A, Palacio A, Verma S, Jones J, Hare J. Uric acid as a predictor of all-cause mortality in heart failure: a meta-analysis. Congestive Heart Failure. 2011;17(1):25-30.

10.Cerezo C, Ruilope JL. Cardiovascular disease prevention - risk assessment and management. ESC. 2012;10(21).

11.Jemadi, Siregar FA, Rasmaliah. Gambaran epideomologi penyakit hipertensi di wilayah kerja puskesmas pecan labuhan kecamatan medan labuhan kota medan provinsi sumatera utara. 2005 [cited 2014 Oct 13]. Available from: http://repository.usu.ac.id/bitstream/1 23456789/18866 /1/ikm-okt 2005.pdf.

12.Muntholib, subandi, wulandari S. Inhibisi xantin oksidase oleh ekstrak etanol kulit melinjo (gnetum gnemon) relatif terhadap allopurinol. 2011 [cited 2014 Oct 13]. Avaible from: http://jurnalonline.um.ac.id/data/artikel.pdf

13.0kafor QH, Collins SP, Jenkins CA, Miller KF, Maron DJ, Naftilan AJ, et al. Relationship between uric acid levels and diagnostic and prognostic outcomes in acute heart failure.The Open Biomarkers Journal. 2012;5:915.

14.Culleton BF, Larson MG, Kannel WB, Levy D. Serum uric acid and risk for cardiovascular disease and death: the framingham heart study. Ann Intern Med. 1999;131:7-13

15.Gazi E, Temiz A, Altun B, Barutcu A, Bekler A, Omer G, et al. The association between serum uric acid level and heard failure and mortality in the early period of st-elevation acute myocardial infarction. Turk Kardiyol Derm Ars - Arch Turk Soc Cardiol. 2014;42(6):501-8.

16.Caraba A, Serban C, Ioan R, Dragan S, Timar R. Uric Acid, Marker of Renal
Dysfunction in Congestive Heart Failure. Experimental \& Clinical Cardiology. 2014;20(8):2106-12.

17.Gustafsson D, Unwin R. The pathophysiology of hyperuricaemia and its possible relationship to cardiovascular disease, morbidity and mortality. BMC Nephrology. 2013 [cited 2015 Jan 5];14:164. Available from:

http://www.biomedcentral.com/14712369/14/164

18.Alcaino $H$, Greig $D$, Chiong $M$, Verdejo H, Miranda R, Concepcion R, et al. Serum uric acid correlates with extracellular superoxide dismutase activity in patient with chronic heart failure. 2007 [cited 2015 Jan 5]. Available from: http://www.captura.uchile.cl/bitstrea m/handle/2250/6615/Alcaino_Hernan .pdf?sequence $=1$.

19.Manampiring AE, Bodhy W. Prevalensi Hiperurisemia pada Remaja Obese di Kota Tomohon [laporan penelitian]. Manado: Universitas Sam Ratulangi; 2011. p. 3-16

20.Efendi D. Korelasi dispersi QT dengan hipertrofi ventrikel kiri pada penderita hipertensi. Medan: Bagian Ilmu Penyakit Dalam Fakultas Kedokteran Universitas Sumatra Utara; 2003.

21.Djohan TBA. Penyakit jantung koroner dan hypertensi. Jurnal e-USU Repository. 2004 [cited 2015 Jan 5]:1-7. Available from: http://library.usu.ac.id/download/fk/gi zi-bahri10.pdf.

22.Rachmadi D. Gangguan Ginjal Akut. Seminar/Workshop nefrologi IDAI cabang Kaltim; 2011 Sep 17; Balikpapan: Fakultas Kedokteran Universitas Padjajaran; 2011.

23.Hatta M. Penyakit periodontal dan hubungannya dengan aterosklerosis [skripsi]. Makassar: Fakultas Kedokteran Gigi Universitas Hasanuddin; 2011. 